Tersedia Online di http://journal2.um.ac.id/index.php/jmsp/

ISSN Online : 2541-4429
PENDIDIKAN

\title{
PERENCANAAN STRATEGI MARKETING MIX DALAM MENINGKATKAN KUANTITAS PESERTA DIDIK
}

\author{
Elvis Fernando Tarantein, Bambang Suteng Sulasmono, Ade Iriani \\ Prodi Magister Manajemen Pendidikan, FKIP, Universitas Kristen Satya Wacana \\ Jl. Diponegoro No.52-60 Salatiga, Jawa Tengah, Indonesia \\ elwayne1390@gmail.com
}

\begin{abstract}
This study aims to produce a product in the form of a marketing mix strategy plan in increasing the quantity of students in Public Senior High School 5 Tual. This research approach uses a research and development (R \& D) approach which consists of 10 (ten) steps that are modified into seven steps, namely potential and problems, data collection, product design, design validation, design revision, product testing, and product revision . Data was collected through observation, interviews, and documentation studies, and FGDs. Data analysis was conducted in two stages, namely qualitative data analysis and SWOT analysis. The results of the study are in the form of a strategic plan developed through R \& D steps by first analyzing the potential and problems faced by the school. Next is data collection from the internal aspects and external aspects of the school. After the data is collected then an analysis of internal factors and external factors is carried out through a SWOT analysis. The results of the SWOT analysis are strategies that are in quadrant IV (weakness threats), which support a defensive strategy. Based on the defensive strategy, the product strategy plan is developed by generating strategies namely: (1) development of the school's superior programs; (2) school management planning programming budgeting system (PPBS); (3) structuring school layout; (4) the use of internet media and school exhibitions as a channel for school promotion; (5) recruitment of teachers and other staff according to priorities and propose the addition of teachers intensively to the government; (6) improvement of facilities and infrastructure through collaboration with the government, parents of students, and local entrepreneurs; and (7) planning learning programs that can attract students' attention.
\end{abstract}

Keywords: strategy, marketing mix, increase quantity of students

\begin{abstract}
Abstrak: Penelitian ini bertujuan untuk menghasilkan produk berupa rencana strategi marketing mix dalam meningkatkan kuantitas peserta didik di SMA Negeri 5 Tual. Pendekatan penelitian ini menggunakan pendekatan penelitian dan pengembangan ( $R$ \& D) yang terdiri dari 10 (sepuluh) langkah yang dimodifikasi menjadi tujuh langkah yaitu potensi dan masalah, pengumpulan data, desain produk, validasi desain, revisi desain, uji coba produk, dan revisi produk. Data dikumpulkan melalui observasi, wawancara, dan studi dokumentasi, dan FGD. Analisis data dilakukan dengan dua tahap yaitu analisis data kualitatif dan analisis SWOT. Hasil penelitian berupa rencana strategi yang dikembangkan melalui langkahlangkah $\mathrm{R} \& \mathrm{D}$ dengan terlebih dahulu menganalisis potensi dan masalah yang dihadapi sekolah. Selanjutnya dilakukan pengumpulan data dari aspek insternal dan aspek eksternal sekolah. Setelah data terkumpul kemudian dilakukan analisis terhadap faktor internal dan faktor eksternal melalui analisis SWOT. Hasil dari analisis SWOT berupa strategi yang berada pada kuadran IV (weakness- threats), yang mendukung strategi defensif. Berdasarkan strategi defensif tersebut, produk rencana strategi dikembangkan dengan menghasilkan strategi yaitu: (1) pengembangan program unggulan sekolah; (2) penataan manajemen planning programming budgeting system (PPBS) sekolah; (3) penataan tata ruang sekolah; (4) pemanfaatan media internet dan pameran sekolah sebagai saluran promosi sekolah; (5) perekrutan guru dan staf lainnya sesuai prioritas serta mengusulkan penambahan guru secara intensif kepada pemerintah; (6) peningkatan sarana dan prasarana melalui kerjasama dengan pemerintah, orang tua peserta didik, maupun pengusaha setempat; dan (7) merencanakan program pembelajaran yang dapat menarik perhatian peserta didik.
\end{abstract}

Kata kunci: strategi, marketing mix, peningkatan kuantitas peserta didik 
Perkembangan ilmu pengetahuan dan teknologi yang semakin pesat membuat masyarakat mulai menyadari tentang pentingnya kualitas pendidikan bagi anak. Masyarakat semakin cerdas memilih lembaga pendidikan yang bermutu dan sesuai dengan yang diinginkan. Hal ini memicu munculnya sekolah-sekolah yang menawarkan berbagai macam konsep pendidikan. Berkaitan dengan hal tersebut, Wijaya (2012: 3) mengemukakan bahwa munculnya sekolah unggulan yang bertaraf internasional serta lahirnya sekolah negeri dan swasta yang menawarkan keunggulan fasilitas, bahkan dengan biaya terjangkau, dapat menambah maraknya kompetisi pendidikan.

Saat ini paradigma dalam memandang pendidikan mulai bergeser, yang awalnya pendidikan dilihat dan dikaji dari aspek sosial, sekarang orang melihat pendidikan lebih pada sebuah corporate (Arifin, 2011: 20). Hal ini berarti bahwa apabila lembaga pendidikan tidak mampu memasarkan jasa pendidikannya dikarenakan mutunya tidak dapat memuaskan konsumen, maka produksi jasa pendidikan yang ditawarkan akan tidak laku di pasaran. Pemasaran yang dilakukan oleh suatu lembaga pendidikan akan memberikan dampak terhadap hubungan sosial sekolah dengan masyarakat serta mampu mengembangkan manajemen lembaga tersebut.

Kotler dan Armstrong (2016: 29) mendefinisikan bahwa pemasaran adalah proses sosial dan manajerial yang dilakukan individu atau kelompok untuk memperoleh kebutuhan dan keinginan, dengan cara membuat serta mempertukarkan produk dan nilai dengan pihak lain. Senada dengan hal tersebut, Machali dan Hidayat (2016: 277) menyebutkan bahwa pemasaran mengandung arti suatu proses sosial dan manajerial yang melibatkan kegiatan-kegiatan penting yang memungkinkan individu dan kelompok mendapatkan kebutuhan dan keinginan melalui pertukaran dengan pihak lain dan untuk mengembangkan hubungan pertukaran.

Dari kedua pendapat tersebut, dapat dikatakan bahwa fungsi penting pemasaran terdiri atas dua hal yaitu proses sosial dan manajerial. Sebagai proses sosial, pemasaran berperan dalam membina hubungan baik antara produsen dan masyarakat. Selain itu, pemasaran menghasilkan standar hidup yang lebih tinggi, apabila produk yang ditawarkan oleh produsen memenuhi kebutuhan dan keinginan masyarakat. Sedangkan sebagai proses manajerial, pemasaran dilakukan agar produsen tetap mengelola dan memperbaiki produk yang dihasilkan sehingga dapat menarik pelanggan baru, serta mempertahankan pelanggan yang sudah ada dengan tetap memegang prinsip kepuasan pelanggan.

Istilah pemasaran (marketing) tidak hanya digunakan oleh lembaga atau organisasi profit saja. Akan tetapi sekolah sebagai salah satu lembaga atau organisasi non profit juga dapat menerapkan pemasaran sebagai salah satu aspek dalam pengelolaan manajemennya. Hal ini dipertegas oleh Muhaimin (2012: 97-98) yang memandang pemasaran dalam konteks pendidikan sebagai pengelolaan yang sistematis dari pertukaran nilai-nilai yang sengaja dilakukan untuk mempromosikan misi sekolah berdasarkan pemenuhan kebutuhan nyata baik itu untuk stakeholder ataupun masyarakat sosial pada umumnya. Lebih lanjut, menurut Muhaimin (2012: 101) fungsi pemasaran di lembaga pendidikan adalah untuk membentuk citra baik terhadap lembaga dan menarik minat sejumlah calon peserta didik. Di sinilah sekolah perlu untuk mengetahui bagaimanakah calon peserta didik dapat melihat sekolah yang dipilihnya.

Sebagai produsen jasa layanan pendidikan, sekolah harus mampu memahami kebutuhan pelanggan sehingga proses pemasaran mengarah pada pemenuhan kebutuhan tersebut. Berhasil tidaknya pemasaran jasa pendidikan sangat berkaitan dengan aktivitas pemenuhan kebutuhan, keinginan, dan harapan dari para pemangku kepentingan sekolah atau pelanggan pendidikan. Lockhart (2011: 5-8) menyebutkan bahwa alasan penting yang mendorong timbulnya pemasaran jasa pendidikan terdiri dari lima faktor yaitu: (1) meningkatnya kompetisi pendidikan; (2) perubahan demografi; (3) ketidakpercayaan masyarakat; (4) penyelidikan media; dan (5) keterbatasan sumber daya.

Berdasarkan alasan tersebut, maka sekolah perlu menerapkan strategi pemasaran yang tepat untuk memenangkan kompetisi pendidikan. Hal ini dipertegas Wijaya (2012: 54-55) bahwa setiap sekolah perlu menetukan dan menerapkan strategi atau cara, serta melakukan aktivitas pemasaran jasa pendidikan agar tetap hidup, berkembang dan mampu bersaing. Aktivitas pemasaran jasa pendidikan yang dilakukan sekolah dapat mengubah penilaian masyarakat terhadap kualitas sekolah dalam jangka panjang dan merupakan cara untuk membangun citra sekolah secara keseluruhan. 
Assauri (2013: 15) menyatakan bahwa strategi pemasaran adalah serangkaian tujuan dan sasaran, kebijakan dan aturan yang memberi arah kepada usaha-usaha pemasaran perusahaan dari waktu ke waktu, pada masing-masing tingkatan dan acuan serta alokasinya, terutama sebagai tanggapan perusahaan dalam menghadapi lingkungan dan keadaan persaingan yang selalu berubah. Dalam perspektif jasa pendidikan, strategi pemasaran dipandang sebagai pemberi arah kepada suatu lembaga pendidikan untuk memuaskan pasar sasaran sesuai visi, misi, maupun tujuannya. Hal yang diperlukan di dalam strategi pemasaran adalah melihat dan menganalisis unsur-unsur yang dimiliki lemabaga pendidikan tersebut sehingga dapat memenuhi kebutuhan pasar sasaran.

Dengan adanya strategi pemasaran, maka implementasi seluruh program lembaga pendidikan akan dapat dilakukan secara aktif, sadar, dan rasional demi mencapai tujuan dari lembaga pendidikan. Selain itu, strategi pemasaran mampu menggerakkan suatu lembaga agar dapat bersaing dengan lembaga lain secara kompetitif.

SMA Negeri 5 Tual merupakan sebuah lembaga pendidikan yang berada di bawah naungan Dinas Pendidikan dan Kebudayaan Provinsi Maluku. Sekolah ini didirikan pada tahun 2014 oleh pemerintah di wilayah desa Taar dengan maksud untuk mengakomodir kebutuhan calon peserta didik sesuai kondisi wilayah tersebut. Substansi dari sekolah ini sama dengan sekolah lain yaitu yaitu ingin menghasilkan generasi penerus bangsa yang berkualitas dari segi karakter, pengetahuan dan keterampilan sesuai dengan yang diamanatkan dalam undang-undang pendidikan.

Sekolah ini berdiri sejak tahun 2014 dan mulai beroperasi pada tahun pelajaran 2014/2015. Total ruang kelas yang tersedia pada sekolah ini hingga tahun pelajaran 2018/2019 adalah 7 (tujuh) ruang kelas, yaitu tiga ruang kelas X (sepuluh), dua ruang kelas XI (sebelas), dan dua ruang kelas XII (dua belas). Saat dilakukan penelitian ini, kepala sekolah dalam wawancaranya mengungkapkan bahwa sekolah telah mendapatkan bantuan sosial dari pemerintah yaitu pembangunan dua ruang kelas baru, yang realisasinya dilakukan pada tahun 2019 ini sehingga ruang kelas akan bertambah menjadi 9 (sembilan) ruang. Jurusan yang tersedia di SMA Negeri 5 Tual terdiri dari dua yaitu IPA dan IPS. Substansi dari sekolah ini sama dengan sekolah-sekolah lain yaitu ingin menghasilkan generasi penerus bangsa yang berkualitas dari segi karakter, pengetahuan dan keterampilan sesuai dengan yang diamanatkan dalam undang-undang pendidikan.

Berdasarkan hasil wawancara dengan kepala sekolah yang dijumpai bahwa jumlah peserta didik dalam penerimaan peserta didik baru setiap tahunnya tidak sesuai dengan target yang diharapkan sekolah. Hal ini dapat dilihat dalam data jumlah peserta didik yang diterima pada penerimaan peserta didik baru SMA Negeri 5 Tual dalam 3 tahun terakhir pada tabel di bawah ini:

Tabel Jumlah Peserta Didik Baru

SMA Negeri 5 Tual Dalam 3 Tahun Terakhir

\begin{tabular}{llll}
\hline \multirow{2}{*}{ Tahun Ajaran } & $\begin{array}{l}\text { Jumlah } \\
\text { Peserta Didik Baru }\end{array}$ & $\begin{array}{l}\text { Jumlah } \\
\text { Ruang Belajar }\end{array}$ & $\begin{array}{l}\text { Target } \\
\text { Peserta Didik Baru }\end{array}$ \\
\hline $2016 / 2017$ & 39 orang & 2 ruang & 72 orang \\
$2017 / 2018$ & 56 orang & 2 ruang & 72 orang \\
$2018 / 2019$ & 75 orang & 3 ruang & 108 orang \\
\hline
\end{tabular}

(Sumber: data PPDB SMA Negeri 5 Tual)

Masalah utama yang dihadapi SMA Negeri 5 Tual adalah minimnya kepercayaan masyarakat terhadap sekolah sebagai penyedia layanan jasa pendidikan bagi mereka, terutama masyarakat desa Taar, dimana lokasi sekolah berada. Masyarakat desa Taar merupakan target utama sekolah dalam menjaring calon peserta didik. Berdasarkan data yang diperoleh dari hasil wawancara dengan pemerintah desa Taar, diperoleh informasi bahwa jumlah masyarakat yang tergolong usia sekolah menengah pertama yang berada pada jenjang akhir rata-rata setiap tahun berjumlah 200 jiwa dari total keseluruhan jumlah penduduk. Selain target utama tersebut, sekolah juga menargetkan jumlah peserta didik yang berasal dari masyarakat sekitar yang bukan penduduk desa Taar. Hal ini karena letak lokasi sekolah berada di antara kelurahan Ketsoblak dan desa Taar. 
Walaupun kebijakan pemerintah tentang sistem zonasi telah dikeluarkan, tetapi sebagian besar masyarakat masih memilih untuk menyekolahkan anaknya di sekolah lain yang dianggap cukup populer. Hal ini didasarkan pada hasil wawancara dengan kepala sekolah bahwa banyak orang tua yang ketar-ketir karena merasa "rugi" jika menyekolahkan anaknya di sekolah baru yang kualitasnya masih diragukan. Bahkan ada yang menyekolahkan anaknya di sekolah sejenis yang berada di kabupaten tetangga. Padahal menurut kepala sekolah bahwa kebijakan tersebut tentunya berdasar pada pertimbangan rasa keadilan untuk memeratakan mutu pendidikan sekolah.

Setelah ditelusuri lebih lanjut mengenai strategi pemasaran yang telah dilakukan, diketahui bahwa ternyata belum ada rencana strategi pemasaran sekolah yang tersusun secara sistematis. Hal ini diakui oleh kepala sekolah bahwa sekolah sama sekali belum pernah melakukan penyusunan rencara strategi pemasaran secara tertulis. Untuk meningkatkan jumlah peserta didik biasanya dilakukan kegiatan promosi menjelang penerimaan peserta didik baru oleh panitianya. Setiap tahunnya promosi dilakukan melalui cara yang sama yaitu pemasangan spanduk dan baliho pada lokasi-lokasi yang dianggap strategis, dan penyebaran brosur kepada masyarakat.

Dari temuan-temuan di atas, maka peneliti berasumsi bahwa ada permasalahan yang dihadapi di SMA Negeri 5 Tual dalam memasarkan jasa pendidikannya. Ternyata sekolah belum sepenuhnya memaksimalkan semua unsur bauran pemasaran yang dimiliki untuk menarik perhatian masyarakat agar dapat menjadi pelanggan terhadap jasa pendidikan yang ditawarkan. Sekolah hanya mengandalkan kegiatan promosi sebagai bentuk strategi untuk memperoleh peserta didik dan itupun hanya dilakukan menjelang penerimaan peserta didik baru. Faktor utama penyebab kekurangan calon peserta didik di SMA Negeri 5 Tual adalah karena sekolah belum memiliki rencana strategi pemasaran yang tersusun dan terarah secara jelas.

Robbins dan Coulter (2009: 160) mengemukakan bahwa rencana strategi merupakan rencanarencana yang berlaku bagi seluruh organisasi, menentukan sasaran umum organisasi tersebut dan berusaha menempatkan organisasi tersebut dalam lingkungannya. Rangkuti (2015: 3) menyebutkan bahwa tujuan utama dilakukan perencanaan strategis adalah agar perusahaan dapat melihat secara objektif kondisi-kondisi internal dan eksternal, sehingga perusahaan dapat mengantisipasi perubahan lingkungan eksternal. Jika dikaitkan dalam pendidikan, rencana strategi diperlukan sekolah karena lingkungan internal maupun eksternal sekolah selalu mengalami perubahan dari waktu ke waktu sehingga melaluinya, sekolah dapat mempertahankan kelangsungannya. Perencanaan strategis sangat penting untuk memperoleh keunggulan bersaing bagi setiap sekolah.

Proses penyusunan rencana strategis dilakukan melalui tiga tahap analisis seperti yang dikemukakan oleh Rangkuti (2015: 23) yaitu: (1) tahap pengumpulan data; (2) tahap analisis; dan (3) tahap pengambilan keputusan. Dalam penelitian ini, kegiatan yang dilakukan dalam tahap pengumpulan data adalah mengidentifikasi faktor-faktor lingkungan internal maupun eksternal sekolah. Selanjutnya, data hasil identifikasi yang telah dikumpulkan dianalisis menggunakan analisis SWOT untuk menentukan strategi yang tepat bagi sekolah, yang diputuskan dalam tahap pengambilan keputusan.

Analisis SWOT telah menjadi alat umum yang digunakan dalam perencanaan strategi pendidikan. Sallis (2012: 221-223) mengemukakan bahwa SWOT adalah singkatan dari strengths, weaknesses, opportunities and threats (kekuatan, kelemahan, peluang, dan ancaman). Strength atau kekuatan yang dimaksud adalah beberapa hal yang merupakan kelebihan dari sekolah yang bersangkutan. Weakness atau kelemahan adalah komponen-komponen yang kurang menunjang suatu keberhasilan penyelenggaraan pendidikan yang ingin dicapai oleh sekolah. Opportunity atau peluang adalah kemungkinan-kemungkinan yang dapat terjadi apabila potensi-potensi yang ada di sekolah tersebut mampu dikembangkan atau dioptimalkan oleh sekolah. Threats atau ancaman adalah kemungkinankemungkinan yang dapat terjadi atau berpengaruh terhadap kesinambungan dan keberlanjutan kegiatan penyelenggaraan di sekolah. Untuk menyikapi masalah yang terjadi di SMA Negeri 5 Tual, maka perlu diianalisis semua unsur bauran pemasaran baik secara internal maupun eksternal. Sekolah sebagai suatu organisasi harus mengetahui dan memanfaatkan secara maksimal semua unsur bauran pemasarannya agar dapat berhasil dalam memasarkan jasa pendidikannya. 
Machali dan Hidayat (2016: 291) menyatakan bahwa bauran pemasaran (marketing mix) adalah unsur-unsur yang sangat penting dan dapat dipadukan sedemikian rupa sehingga dapat menghasilkan strategi pemasaran yang dapat memenangkan persaingan. Kotler dan Amstrong (2016: 78) mengemukakan bahwa: "marketing mix is the set of controllable tactical marketing tools that the firm blends to produce the response it wants in the target market". Hal ini berarti bahwa bauran pemasaran adalah kumpulan alat pemasaran taktis terkendali yang dipadukan perusahaan untuk menghasilkan respons yang diinginkannya di pasar sasaran.

Machali dan Hidayat (2016: 292) unsur-unsur yang terdapat dalam bauran pemasaran jasa pendidikan terdiri atas 7 hal yang biasanya disingkat dengan 7P di antaranya: (1) product (produk) yaitu jasa seperti apa yang ditawarkan; (2) price (harga) yaitu strategi penentuan harganya; (3) place (lokasi/tempat) yaitu dimana tempat jasa diberikan; (4) promotion (promosi) yaitu bagaimana promosi dilakukan; (5) people (sumber daya manusia), yaitu kualitas, kualifikasi, dan kompetensi yang dimiliki orang yang terlibat dalam pemberian jasa; (6) phisycal evidence (bukti fisik) yaitu sarana prasarana seperti apa yang dimiliki; dan (7) process (proses) yaitu manajemen layanan pembelajaran yang diberikan.

Penelitian ini bertujuan mengembangkan rencana strategi pemasaran yang terintegrasi marketing mix di SMA Negeri 5 Tual. Marketing Mix dipilih dalam pengembangan strategi pemasaran karena berorientasi pada seluruh unsur bauran pemasaran jasa pendidikan, sehingga hasil penelitian ini diharapkan dapat memberikan rekomendasi kepada seluruh stakeholder sekolah untuk mendayagunakan seluruh potensi marketing mix sekolah dalam memasarkan jasa pendidikannya.

\section{METODE}

Metode yang digunakan dalam penelitian ini adalah penelitian dan pengembangan ( $\mathrm{R} \& \mathrm{D}$ ). Menurut Sugiyono (2009: 407), penelitian pengembangan adalah metode penelitian yang digunakan untuk menghasilkan produk tertentu, dan menguji keefektifan produk tersebut. Langkah-langkah dalam penelitian dan pengembangan tersebut terdiri dari 10 (sepuluh) langkah (Sugiyono, 2009: 409) di antaranya yaitu: (1) potensi dan masalah, (2) pengumpulan data, (3) desain produk, (4) validasi desain, (5) revisi desain, (6) uji coba produk, (7) revisi produk, (8) uji coba pemakaian, (9) revisi produk, dan (10) produk masal. Mengingat waktu penelitian yang cukup singkat dan terbatas, maka langkah-langkah penelitian dan pengembangan dibatasi sampai pada tahapan ketujuh yaitu revisi produk.

Pada langkah pertama dalam penelitian ini, peneliti mengidentifikasi potensi dan masalah pada SMA Negeri 5 Tual berdasarkan tujuh unsur bauran pemasaran. Potensi-potensi tersebut dapat dilihat berdasarkan kekuatan dan peluang, di dalam hasil analisis SWOT. Sedangkan masalah dialami oleh SMA Negeri 5 Tual dilihat dari kelemahan dan dan ancaman yang ada di dalam hasil analisis SWOT. Potensi dan masalah ini diperoleh berdasarkan hasil observasi, wawancara, dan studi dokumentasi.

Setelah potensi dan masalah ditemukan, maka langkah selanjutnya perlu dikumpulkan berbagai informasi yang dapat digunakan sebagai bahan untuk merencanakan pembuatan rencana strategi pemasaran sekolah yang diharapkan dapat mengatasi masalah tersebut. Pengumpulan data dilakukan melalui dua hal yakni studi literatur dan pengumpulan informasi. Studi literatur dilakukan untuk mencari teori-teori tentang strategi yang akan digunakan (strategi marketing mix). Sedangkan pengumpulan informasi dilakukan melalui FGD untuk mengkonfirmasi faktor-faktor internal dan eksternal sekolah yang telah diidentifikasi berdasarkan hasil observasi, wawancara, dan studi dokumentasi. Selanjutnya di dalam FGD tersebut dilakukan penentuan bobot dan rating dari setiap hasil identifikasi.

Langkah selanjutnya adalah melakukan desain produk. Desain produk dalam penelitian ini berupa draft rencana strategis pemasaran sekolah di SMA Negeri 5 Tual. Rencana strategis ini belum teruji oleh para pakar sehingga belum diketahui kelemahannya. Oleh karena itu, pada langkah yang berikut dilakukan validasi desain. Validasi desain dilakukan untuk menilai apakah produk yang dikembangkan untuk mewujudkan tujuan secara rasional akan lebih efektif ataukah tidak. Validasi ini masih bersifat penilaian berdasarkan pemikiran rasional, belum ada fakta lapangan. Validasi ini dilakukan oleh tiga validator yaitu ahli pembuatan renstra, ahli pengembangan, dan praktisi pendidikan di sekolah. Masukan 
dari ahli atau pakar ini akan digunakan sebagai bahan untuk perbaikan draft renstra pada tahap revisi desain.

Tahap selanjutnya, desain produk rencana strategis (renstra) pemasaran sekolah yang telah divalidasi dan direvisi diujicobakan secara terbatas. Uji coba produk dapat dilakukan dengan meminta pandangan atau persepsi dari semua stakeholder sekolah untuk memberikan masukan tentang estimasi keberhasilan strategi yang nanti digunakan pada masa yang akan datang. Hal ini dilakukan dengan alasan karena mengingat waktu penelitian yang relatif singkat. Berdasakan pengujian terhadap produk sesuai dengan persepsi seluruh stakeholder sekolah, apabila perlu ada perbaikan maka dilakukan revisi produk. Hasil revisi tersebut kemudian dibukukan dan diserahkan kepada kepala sekolah sebagai panduan dalam pelaksanaan kegiatan pemasaran di sekolah.

Penelitian ini dilakukan di SMA Negeri 5 Tual yang berlokasi di Jalan Hoat Taar, Desa Taar, Kota Tual, Provinsi Maluku. Pengumpulan data berlangsung pada bulan Oktober 2018 sampai bulan Januari 2019. Subjek penelitian terdiri dari kepala sekolah, staf, dan komite sekolah sebagai subjek dalam penelitian ini. Teknik pengumpulan data yang digunakan dalam penelitian ini adalah observasi, wawancara, dan studi dokumen. Teknik observasi dilakukan dengan berpedoman pada instrumen checklist dengan tujuan untuk mengamati secara langsung kondisi sekolah. Teknik wawancara menggunakan instrumen pedoman wawancara dengan tujuan untuk mengetahui faktor-faktor internal dan eksternal sekolah. Teknik studi dokumentasi dilakukan untuk mengetahui dokumen dan bukti-bukti fisik yang berkaitan dengan pemasaran sekolah. Data yang diperoleh dari hasil observasi, wawancara, dan studi dokumentasi dianalisis secara kualitatif. Selanjutnya data kualitatif tersebut dianalisis dengan menggunakan teknik analisis SWOT untuk menentukan strategi yang tepat dalam merancang produk rencana strategi pemasaran sekolah.

Untuk menjamin keabsahan data serta kedalaman dan kejelasan pemahaman terhadap pemasaran sekolah, maka digunakan teknik triangulasi. Teknik triangulasi yang digunakan adalah triangulasi teknik dan triangulasi sumber. Triangulasi teknik yang digunakan adalah focus group discussion (FGD), bertujuan untuk mengkonfirmasi faktor-faktor internal dan eksternal yang telah diidentifikasi sesuai hasil observasi, wawancara, dan studi dokumentasi. Selain itu, FGD juga digunakan untuk mengetahui persepsi stakeholder sekolah tentang estimasi keberhasilan produk rencana strategi yang telah dibuat.

\section{HASIL DAN PEMBAHASAN}

Hasil penelitian yang diperoleh dari observasi, wawancara, studi dokumentasi, dan FGD dibahas berdasarkan tujuh tahapan penelitian yang digunakan yaitu: (1) potensi dan masalah, (2) pengumpulan data, (3) desain produk, (4) validasi desain, (5) revisi desain, (6) uji coba produk, dan (7) revisi produk.

\section{Potensi dan Masalah}

Potensi yang dapat dimanfaatkan dan masalah yang dihadapi sekolah diperoleh dari hasil observasi, wawancara, dan studi dokumentasi. Potensi dan masalah tersebut dikaji dari tujuh unsur bauran pemasaran yaitu product (produk), price (harga), place (lokasi), promotion (promosi), people (sumber daya manusia), phisycal evidence (bukti fisik), dan process (proses).

Dalam unsur product, potensi yang dapat dimanfaatkan adalah prestasi yang dimiliki sekolah baik secara akademik non akademik. Sedangkan masalah yang dihadapi di dalam unsur ini adalah pembelajaran di SMA Negeri 5 Tual belum menggunakan kurikulum berbasis kearifan lokal untuk mewujudkan program unggulan sekolah (pembelajaran bahasa kei), serta program ekstrakurikuler yang belum dilakukan secara optimal. Selain itu, sebagian besar lulusan tidak melanjutkan pendidikan ke jenjang perguruan tinggi sejak kelulusan dua tahun terakhir juga menjadi permasalahan yang dihadapi sekolah.

Selanjutnya pada unsur price, terdapat beberapa potensi yang dapat dimanfaatkan yaitu adanya sumber dana pendidikan sekolah yang jelas, biaya pendidikan di sekolah cenderung lebih murah, adanya 
dispensasi dan syarat cicilan pembayaran biaya pendidikan, dan tranparansi penggunaan dana BOS. Akan tetapi permasalahan yang dihadapi di dalam unsur ini adalah terbatasnya dana sekolah untuk membiayai kebutuhan sekolah.

Beberapa potensi unsur place yang ditemukan yaitu letak lokasi sekolah berdekatan dengan pemukiman masyarakat desa yang berpotensi menjadi calon pelanggan sekolah, kemudahan akses menuju sekolah, dan letak lokasi sekolah yang tenang dan terhindar kemacetan. Akan tetapi permasalahan yang dihadapi di dalam unsur ini adalah terbatasnya lahan untuk perluasan pembangunan maupun usaha sekolah.

Kemudian pada unsur promotion, ditemukan juga beberapa potensi yang dapat dimanfaatkan oleh sekolah yaitu keterlibatan sekolah dalam berbagai kegiatan penting yang diselenggarakan oleh pemerintah maupun masyarakat, program promosi secara langsung melalui kegiatan sosialisasi langsung maupun tertulis melalui brosur dan spanduk menjelang PPDB, serta program "santa claus". Akan tetapi permasalahan yang dihadapi di dalam unsur ini adalah pemanfaatan internet sebagai media promosi belum dilakukan secara optimal, serta belum ada program kerjasama yang dilakukan sekolah dengan alumni untuk membantu mempromosikan sekolah. Potensi di dalam unsur people yang dapat dimanfaatkan adalah kualifikasi pendidikan yang dimiliki oleh kepala sekolah dan seluruh guru di sekolah adalah sarjana pendidikan. Sedangkan masalah yang dihadapi dalam unsur ini adalah jumlah guru yang tersedia belum memadai.

Potensi yang dapat dimanfaatkan dalam unsur physical evidence adalah lahan sekolah sudah bersertifikat sejak tahun 2017, dan sekolah juga memiliki ruang belajar yang representatif. Sedangkan permasalahan yang dihadapi di dalam unsur ini adalah minimnya fasilitas penunjang pembelajaran yang dimiliki sekolah. Pada unsur process, terdapat beberapa potensi yang dapat dimanfaatkan yaitu adanya proses pembinaan karakter melalui bimbingan rohani. Sedangkan permasalahan yang dihadapi dalam unsur ini adalah perencanaan pembelajaran belum tersitematis.

\section{Pengumpulan Data}

Untuk menyusun rencana strategi terlebih dahulu dikumpulkan data mengenai aspek internal dan eksternal yang berpengaruh terhadap pemasaran sekolah. Berdasarkan data hasil observasi, hasil studi dokumentasi, dan hasil wawancara, maka diidentifikasi faktor-faktor internal dan eksternal yang ada di SMA Negeri 5 Tual. Data hasil identifikasi tersebut masih bersifat sementara, sehingga perlu dikonfirmasi dan dianalisis lebih lanjut melalui FGD dengan semua stakeholder sekolah. Hasil yang diperoleh berdasarkan hasil FGD disajikan dalam tabel 1 dan tabel 2 di bawah ini.

Pada tabel 1, penentuan bobot pada masing-masing IFAS (internal factors analysis summary) dilakukan dengan dengan skala mulai dari 0,0 (tidak penting) sampai 1,0 (sangat penting). Faktor-faktor tersebut kemungkinan dapat memberikan dampak terhadap faktor strategis secara internal. Sedangkan rating dari masing-masing faktor ditentukan berdasarkan skala mulai dari 4 (outstanding) sampai dengan 1 (poor) berdasarkan pengaruh faktor tersebut terhadap kondisi internal sekolah. Kemudian dilakukan perkalian bobot dan rating sehingga diperoleh total skor dari faktor kekuatan maupun kelemahan. Sedangkan pada bagian kolom akhir, diberikan komentar atau catatan inti meneganai alasan pemilihan faktor-faktor internal sekolah tersebut.

Tabel 1. Perhitungan IFAS (Internal Factors Analysis Summary)

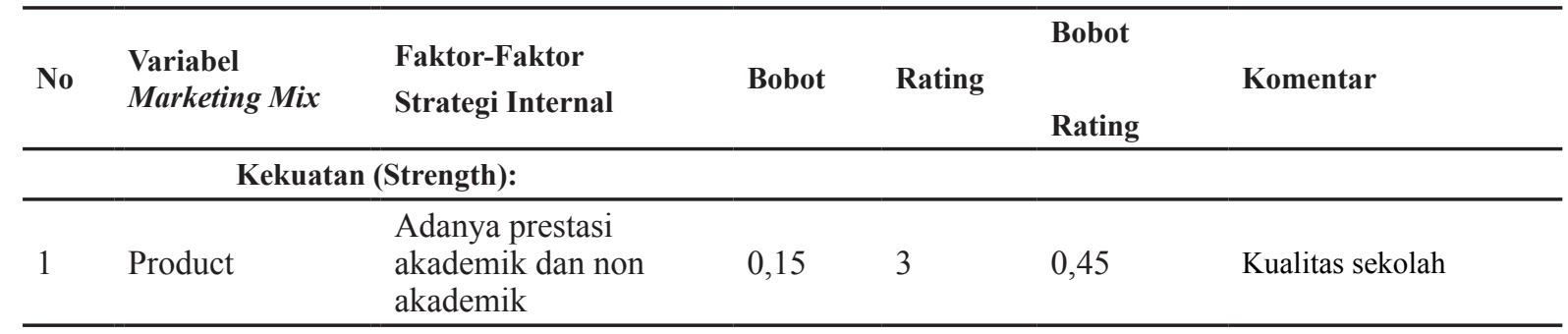




\begin{tabular}{|c|c|c|c|c|c|c|}
\hline 2 & Price & $\begin{array}{l}\text { Adanya kemudahan } \\
\text { dan keterbukaan } \\
\text { di dalam sistem } \\
\text { pembiayaan pendidikan }\end{array}$ & 0,10 & 3 & 0,30 & $\begin{array}{l}\text { Reputasi keuangan } \\
\text { tinggi }\end{array}$ \\
\hline 3 & Place & $\begin{array}{l}\text { Letak lokasi sekolah } \\
\text { mudah diakses dan } \\
\text { dapat dijangkau }\end{array}$ & 0,15 & 4 & 0,45 & $\begin{array}{l}\text { Biaya transportasi } \\
\text { rendah }\end{array}$ \\
\hline 4 & Promotion & $\begin{array}{l}\text { Adanya akun virtual } \\
\text { dan program promosi } \\
\text { sekolah }\end{array}$ & 0,20 & 4 & 0,80 & $\begin{array}{l}\text { Dapat menjadi media } \\
\text { promosi dalam era } \\
\text { modern }\end{array}$ \\
\hline 5 & People & $\begin{array}{l}\text { Kualifikasi dan kualitas } \\
\text { tenaga pengajar } \\
\text { memadai }\end{array}$ & 0,15 & 2 & 0,30 & $\begin{array}{l}\text { Berijasah sarjana } \\
\text { pendidikan }\end{array}$ \\
\hline 6 & $\begin{array}{l}\text { Physical } \\
\text { Evidence }\end{array}$ & $\begin{array}{l}\text { Lahan sekolah telah } \\
\text { bersertifikat serta } \\
\text { tersedianya ruang } \\
\text { belajar dan fasilitas } \\
\text { internet yang memadai }\end{array}$ & 0,10 & 3 & 0,30 & $\begin{array}{l}\text { Kenyamanan dan } \\
\text { kemudahan belajar }\end{array}$ \\
\hline 7 & Process & $\begin{array}{l}\text { Adanya program } \\
\text { pembinaan karakter }\end{array}$ & 0,15 & 4 & 0,60 & $\begin{array}{l}\text { Harapan orang tua } \\
\text { terhadap karakter buruk } \\
\text { anak }\end{array}$ \\
\hline Tot & Skor & & 1 & & 3,35 & \\
\hline No & $\begin{array}{l}\text { Variabel } \\
\text { Marketing Mix }\end{array}$ & $\begin{array}{l}\text { Faktor-Faktor } \\
\text { Strategi Internal }\end{array}$ & Bobot & Rating & $\begin{array}{l}\text { Bobot } \\
\text { Rating } \\
\end{array}$ & Komentar \\
\hline & Kelem & an (Weakness): & & & & \\
\hline 1 & Product & $\begin{array}{l}\text { Program akademik } \\
\text { maupun non akademik } \\
\text { belum terjadwal secara } \\
\text { sistemtis }\end{array}$ & 0,20 & 4 & 0,80 & $\begin{array}{l}\text { Belum ada program } \\
\text { unggulan }\end{array}$ \\
\hline 2 & Price & $\begin{array}{l}\text { Terbatasnya jumlah } \\
\text { anggaran sekolah, } \\
\text { transpransi anggaran, } \\
\text { dan sistem layanan } \\
\text { pembayaran biaya } \\
\text { pendidikan }\end{array}$ & 0,20 & 4 & 0,80 & $\begin{array}{l}\text { Sistem pembiayaan } \\
\text { terbatas }\end{array}$ \\
\hline 3 & Place & Lahan sekolah terbatas & 0,10 & 3 & 0,30 & $\begin{array}{l}\text { Lemahnya penataan } \\
\text { lahan }\end{array}$ \\
\hline 4 & Promotion & $\begin{array}{l}\text { Kegiatan promosi } \\
\text { belum dilakukan } \\
\text { secara optimal }\end{array}$ & 0,10 & 2 & 0,20 & Terbatas pada PPDB \\
\hline 5 & People & $\begin{array}{l}\text { Jumlah staf sekolah } \\
\text { belum memadai }\end{array}$ & 0,10 & 4 & 0,40 & Jumlah staf terbatas \\
\hline 6 & $\begin{array}{l}\text { Physical } \\
\text { Evidence }\end{array}$ & $\begin{array}{l}\text { Sarana dan prasarana } \\
\text { pendukung proses } \\
\text { pendidikan belum } \\
\text { memadai }\end{array}$ & 0,20 & 4 & 0,80 & $\begin{array}{l}\text { Fasilitas sains, olahraga, } \\
\text { dan kesenian terbatas }\end{array}$ \\
\hline 7 & Process & $\begin{array}{l}\text { Perencanaan program } \\
\text { di sekolah belum } \\
\text { sistematis }\end{array}$ & 0,10 & 2 & 0,20 & $\begin{array}{l}\text { Pelaksanaan program } \\
\text { masih bersifat dadakan }\end{array}$ \\
\hline \multicolumn{3}{|c|}{ Total Skor } & 1 & & 3,50 & \\
\hline \multicolumn{3}{|c|}{ Total Skor Akhir (Strength - Weakness) } & \multicolumn{2}{|c|}{$3,35-3,50$} & $-0,15$ & \\
\hline
\end{tabular}


Pada tabel 2, penentuan bobot pada masing-masing EFAS (eksternal factors analysis summary) dilakukan dengan dengan skala mulai dari 0,0 (tidak penting) sampai 1,0 (sangat penting). Faktor-faktor tersebut kemungkinan dapat memberikan dampak terhadap faktor strategis secara eksternal. Sedangkan rating dari masing-masing faktor ditentukan berdasarkan skala mulai dari 4 (outstanding) sampai dengan 1 (poor) berdasarkan pengaruh faktor tersebut terhadap kondisi eksternal sekolah. Kemudian dilakukan perkalian bobot dan rating sehingga diperoleh total skor dari faktor peluang maupun ancaman. Sedangkan pada bagian kolom akhir, diberikan komentar atau catatan inti meneganai alasan pemilihan faktor-faktor internal sekolah tersebut.

Tabel 2. Perhitungan IFAS (Eksternal Factors Analysis Summary)

\begin{tabular}{|c|c|c|c|c|c|c|}
\hline \multirow{3}{*}{ No } & \multirow{3}{*}{$\begin{array}{l}\text { Variabel } \\
\text { Marketing Mix }\end{array}$} & \multirow{3}{*}{$\begin{array}{l}\text { Faktor-Faktor } \\
\text { Strategi Eksternal }\end{array}$} & \multirow{3}{*}{ Bobot } & \multirow{3}{*}{ Rating } & \multicolumn{2}{|l|}{ Bobot } \\
\hline & & & & & & Komentar \\
\hline & & & & & Rating & \\
\hline \multicolumn{7}{|c|}{ Peluang (Opportunity): } \\
\hline 1 & Product & $\begin{array}{l}\text { Bahasa lokal hampir } \\
\text { punah dan partisipasi } \\
\text { aktif peserta didik di } \\
\text { masyarakat }\end{array}$ & 0,15 & 4 & 0,60 & $\begin{array}{l}\text { Banyak orang mulai } \\
\text { ingin belajar bahasa } \\
\text { lokal, partisipasi } \\
\text { menunjukkan mutu }\end{array}$ \\
\hline 2 & Price & Dukungan komite & 0,10 & 4 & 0,40 & $\begin{array}{l}\text { Kepedulian komite } \\
\text { terhadap kesejahteraan } \\
\text { guru }\end{array}$ \\
\hline 3 & Place & $\begin{array}{l}\text { Kebijakan pemerintah } \\
\text { dan letak geografis } \\
\text { sekolah }\end{array}$ & 0,15 & 2 & 0,30 & $\begin{array}{l}\text { Sistem zonasi yang telah } \\
\text { diberlakukan }\end{array}$ \\
\hline 4 & Promotion & $\begin{array}{l}\text { Dukungan dari } \\
\text { pemerintah desa dan } \\
\text { eksistensi masyarakat } \\
\text { dalam penggunaan } \\
\text { media sosial semakin } \\
\text { tinggi }\end{array}$ & 0,20 & 4 & 0,80 & $\begin{array}{l}\text { Pemerintah desa jadi } \\
\text { promotor, penggunaan } \\
\text { media sosial semakin } \\
\text { tinggi }\end{array}$ \\
\hline 5 & People & $\begin{array}{l}\text { Banyaknya pencari } \\
\text { kerja di daerah setempat } \\
\text { yang bergelar sarjana } \\
\text { pendidikan }\end{array}$ & 0,15 & 3 & 0,45 & $\begin{array}{l}\text { Pencari kerja terbanyak } \\
\text { adalah lulusan guru }\end{array}$ \\
\hline 6 & $\begin{array}{l}\text { Physical } \\
\text { Evidence }\end{array}$ & $\begin{array}{l}\text { Adanya perhatian } \\
\text { khusus pemerintah } \\
\text { terhadap pembangunan } \\
\text { fisik bagi sekolah- } \\
\text { sekolah baru }\end{array}$ & 0,10 & 3 & 0,30 & $\begin{array}{l}\text { Bantuan pembangunan } \\
\text { dari pemerintah masih } \\
\text { diperoleh }\end{array}$ \\
\hline 7 & Process & $\begin{array}{l}\text { Potensi lokal daerah dan } \\
\text { perkembangan IPTEK }\end{array}$ & 0,15 & 3 & 0,45 & $\begin{array}{l}\text { Potensi khas daerah } \\
\text { menjadi bahan } \\
\text { pembelajaran }\end{array}$ \\
\hline Tot & Skor & & 1 & & 3,30 & \\
\hline No & $\begin{array}{l}\text { Variabel } \\
\text { Marketing Mix }\end{array}$ & $\begin{array}{l}\text { Faktor-Faktor } \\
\text { Strategi Eksternal }\end{array}$ & Bobot & Rating & $\begin{array}{l}\text { Bobot } \\
\text { Rating } \\
\end{array}$ & Komentar \\
\hline \multicolumn{7}{|c|}{ Ancaman (Threats): } \\
\hline 1 & Product & $\begin{array}{l}60 \% \text { lulusan sekolah } \\
\text { tidak melanjutkan } \\
\text { pendidikan di jenjang } \\
\text { perguruan tinggi }\end{array}$ & 0,20 & 4 & 0,80 & $\begin{array}{l}\text { Tantangan terhadap } \\
\text { akreditas sekolah }\end{array}$ \\
\hline
\end{tabular}




\begin{tabular}{|c|c|c|c|c|c|c|}
\hline 2 & Price & $\begin{array}{l}\text { Kebijakan pemerintah } \\
\text { daerah provinsi dan } \\
\text { kondisi ekonomi } \\
\text { masyarakat }\end{array}$ & 0,20 & 4 & 0,80 & $\begin{array}{l}\text { Program sekolah } \\
\text { menjadi terhambat }\end{array}$ \\
\hline 3 & Place & $\begin{array}{l}\text { Kondisi lahan kosong } \\
\text { di sekitar sekolah dan } \\
\text { letak geografis kota Tual } \\
\text { dengan ibu kota provinsi }\end{array}$ & 0,10 & 3 & 0,30 & $\begin{array}{l}\text { Keindahan lokasi } \\
\text { sekolah terganggu, } \\
\text { tantangan bagi sekolah } \\
\text { dalam pengurusan } \\
\text { kepentingan sekolah }\end{array}$ \\
\hline 4 & Promotion & $\begin{array}{l}\text { Paradigma negatif } \\
\text { masyarakat terhadap } \\
\text { sekolah baru }\end{array}$ & 0,10 & 4 & 0,40 & $\begin{array}{l}\text { Tantangan besar untuk } \\
\text { mengubah paradigma } \\
\text { negatif }\end{array}$ \\
\hline 5 & People & $\begin{array}{l}\text { Kebijakan pemerintah } \\
\text { tentang pengalihan } \\
\text { kewenangan pendidikan }\end{array}$ & 0,10 & 4 & 0,40 & $\begin{array}{l}\text { Pengaruh kebijakan } \\
\text { menjadi ancaman dalam } \\
\text { pengurusan peningkatan } \\
\text { karir dan jumlah guru }\end{array}$ \\
\hline 6 & $\begin{array}{l}\text { Physical } \\
\text { Evidence }\end{array}$ & $\begin{array}{l}\text { Rendahnya partisipasi } \\
\text { orang tua dalam } \\
\text { pembangunan atau } \\
\text { pengadaan sarpras di } \\
\text { sekolah }\end{array}$ & 0,20 & 2 & 0,40 & $\begin{array}{l}\text { Kesepakatan sering } \\
\text { dilanggar }\end{array}$ \\
\hline 7 & Process & $\begin{array}{l}\text { Rendahnya kepedulian } \\
\text { orang tua terhadap } \\
\text { waktu belajar anak } \\
\text { di rumah serta belum } \\
\text { ada kerjasama dengan } \\
\text { lembaga lain sebagai } \\
\text { sumber belajar alternatif }\end{array}$ & 0,10 & 3 & 0,30 & $\begin{array}{l}\text { Menjadi ancaman } \\
\text { bagi sekolah untuk } \\
\text { meningkatkan frekuensi } \\
\text { belajar peserta didik }\end{array}$ \\
\hline \multicolumn{2}{|c|}{ Total Skor } & & \multicolumn{2}{|l|}{1} & 3,40 & \\
\hline \multicolumn{3}{|c|}{ Total Skor Akhir (Opportunity - Threats) } & \multicolumn{2}{|c|}{$3,40-3,30$} & $-0,10$ & \\
\hline
\end{tabular}

Total skor akhir dari hasil perhitungan IFAS dan EFAS yang telah diperoleh dari perhitungan IFAS dan EFAS di atas, kemudian dijadikan titik koordinat dalam diagram analisis SWOT seperti yang ditunjukkan dalam gambar 1. Kuadran I pada diagram menyatakan situasi yang sangat menguntungkan, karena sekolah memiliki peluang dan kekuatan yang baik. Adapun strategi yang harus diterapkan dalam kondisi ini yaitu strategi yang mendukung kebijakan pertumbuhan yang agresif atau strategi agresif. Kuadran II menyatakan bahwa meskipun sekolah menghadapi berbagai ancaman dari luar, namun sekolah masih memiliki kekuatan dari segi internal. Strategi yang perlu diterapkan yaitu strategi diversifikasi yang mana kekuatan yang ada digunakan untuk mengatasi ancaman yang datang dari luar. Kuadran III menyatakan bahwa sekolah menghadapi peluang dari luar yang sangat besar, tetapi di lain pihak sekolah juga menghadapi beberapa kelemahan internal atau kendala. Fokus sekolah pada strategi ini adalah meminimalkan masalah-masalah internal sehingga dapat menggunakan peluang dari luar yang lebih baik dengan menerapkan strategi turn-around. Sedangkan kuadran IV menyatakan situasi yang sangat tidak menguntungkan karena sekolah menghadapi berbagai ancaman dari luar dan memiliki kelemahankelemahan internal, sehingga untuk mengatasinya sekolah perlu menerapkan strategi defensif. 


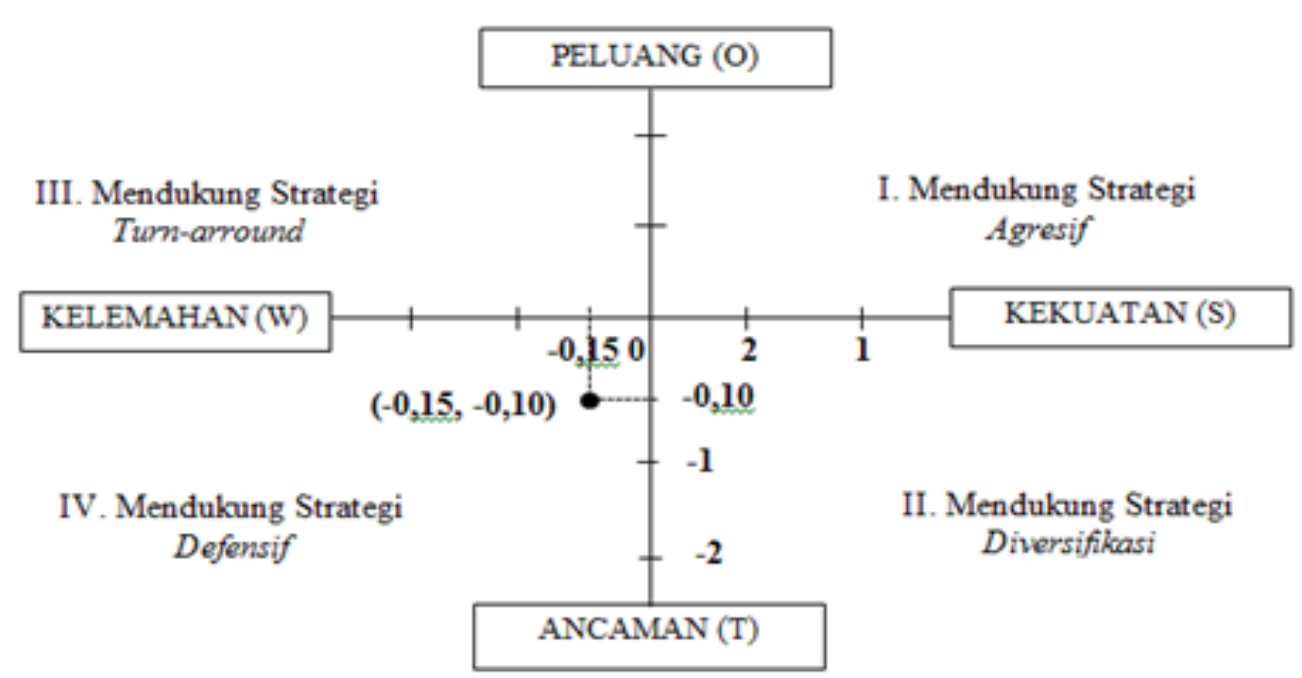

Gambar 1. Diagram Hasil Analisis SWOT

Pada gambar 1, terlihat bahwa total skor akhir IFAS merupakan titik koordinat pada sumbu $x$, sedangkan total skor akhir EFAS merupakan titik koordinat pada sumbu $y$. Hal ini dilakukan dengan tujuan untuk mengetahui posisi strategi pemasaran yang tepat di SMA Negeri 5 Tual. Berdasarkan hasil analisis yang ditunjukkan pada gambar 1, SMA Negeri 5 Tual berada pada kuadran IV (weaknessthreats), yang berarti bahwa sekolah menghadapi berbagai ancaman dan kelemahan internal. Oleh karena itu, strategi yang direkomendasikan adalah strategi defensif yaitu strategi yang digunakan untuk meminimalisir kelemahan sekolah dan menghindari ancaman yang dihadapi sekolah. Strategi ini adalah strategi yang perlu dipertahankan sambil sekolah terus berupaya membenahi diri.

\section{Desain Produk}

Setelah diketahui posisi strategi yang terletak pada kuadran IV (WT) sesuai hasil analisis SWOT, maka produk yang dikembangkan didesain seperti yang tersaji pada tabel 3 .

Tabel 3. Desain Strategi Berdasarkan Hasil Analisis SWOT

\begin{tabular}{ll}
\hline Faktor eksternal & Ancaman $\mathbf{( T )}$ \\
\hline 1. $60 \%$ lulusan sekolah tidak melanjutkan pendidikan \\
di jenjang perguruan tinggi \\
2. Kebijakan pemerintah daerah provinsi dan kondisi \\
ekonomi masyarakat \\
3. Kondisi lahan kosong di sekitar sekolah dan letak \\
geografis kota Tual dengan ibu kota provinsi \\
4. Paradigma negatif masyarakat terhadap sekolah \\
baru \\
5. Kebijakan pemerintah tentang pengalihan \\
kewenangan pendidikan \\
6. Rendahnya partisipasi orang tua dalam \\
pembangunan atau pengadaan sarpras di sekolah \\
7. Rendahnya kepedulian orang tua terhadap waktu \\
belajar anak di rumah serta belum ada kerjasama \\
dengan lembaga lain sebagai sumber belajar alternatif \\
\hline
\end{tabular}




\begin{tabular}{ll}
\hline Kelemahan $(\mathbf{W})$ & Strategi Weakness-Threats \\
\hline 1. Program akademik maupun non akademik belum & 1. Pengembangan program unggulan sekolah \\
terjadwal secara sistemtis & 2. Penataan manajemen planning programming \\
2. Terbatasnya jumlah anggaran sekolah, transpransi & budgeting system (PPBS ) sekolah \\
anggaran, dan sistem layanan pembayaran biaya & 3. Penataan tata ruang sekolah \\
pendidikan & 4. Pemanfaatan media internet dan pameran sekolah \\
3. Lahan sekolah terbatas & sebagai saluran promosi sekolah \\
4. Kegiatan promosi belum dilakukan secara optimal & 5. Perekrutan guru dan staf lainnya sesuai prioritas \\
5. Jumlah staf sekolah belum memadai & serta mengusulkan penambahan guru secara intensif \\
6. Sarana dan prasarana pendukung proses pendidikan & kepada pemerintah \\
belum memadai & 6. Peningkatan sarana dan prasarana melalui \\
7. Perencanaan program di sekolah belum sistematis & kerjasama dengan pemerintah, orang tua peserta didik, \\
& maupun pengusaha setempat \\
& 7. Merencanakan program pembelajaran yang dapat \\
\end{tabular}

Berdasarkan strategi (weakness-threat) tersebut maka akan dikaji isu-isu strategis, yang kemudian dikembangkan menjadi desain produk berupa draft desain rencana strategis marketing mix dalam meningkatkan jumlah peserta didik di SMA Negeri 5 Tual.

\section{Validasi Desain}

Produk yang dikembangkan berupa rencana strategi marketing mix dalam meningkatkan kuantitas peserta didik di SMA Negeri 5 Tual, divalidasi oleh 3 validator ahli dan 1 validator praktisi. Validator ahli adalah Prof. Dr. Slameto, M.Pd, Dr. Bambang Ismanto, M.Si, dan Dr. Yari Dwikurnaningsih, M.Pd. Ketiga validator ahli tersebut seluruhnya merupakan dosen PPs-MMP UKSW Salatiga. Sedangkan validator praktisi adalah Fransina Silpa Songjanan, S.Pd selaku kepala SMA Negeri 5 Tual.

Hal-hal yang divalidasi berupa 20 pernyataan yang berkaitan dengan desain produk rencana strategi, yang diukur menggunakan 5 pilihan skala Likert. Skala 1 menyatakan pernyataan sangat kurang sesuai, skala 2 menyatakan pernyataan kurang sesuai, skala 3 menyatakan pernyataan cukup sesuai, skala 4 menyatakan pernyataan sesuai, dan skala 5 menyatakan pernyataan sangat sesuai.

Hasil penilaian dari validator pertama (Prof. Dr. Slameto, M.Pd) yaitu jumlah pernyataan yang dinilai pada skala 3 sebanyak 10 pernyataan atau sebesar 50\%, artinya "pernyataan cukup sesuai", dan jumlah pernyataan yang dinilai pada skala 4 sebanyak 10 pernyataan atau sebesar $50 \%$ artinya "pernyataan sesuai".

Hasil penilaian dari validator kedua (Dr. Bambang Ismanto, M.Si) yaitu jumlah pernyataan yang dinilai pada skala 2 sebanyak 9 pernyataan atau sebesar $45 \%$, artinya "pernyataan kurang sesuai", jumlah pernyataan yang dinilai pada skala 3 sebanyak 10 pernyataan atau sebesar $50 \%$, artinya "pernyataan cukup sesuai", dan jumlah pernyataan yang dinilai berada pada skala 4 sebanyak 1 pernyataan atau sebesar $5 \%$ artinya "pernyataan sesuai".

Hasil penilaian dari validator ketiga (Dr. Yari Dwikurnaningsih, M.Pd) yaitu jumlah pernyataan yang dinilai pada skala 4 sebanyak 17 pernyataan atau sebesar $85 \%$, artinya "pernyataan sesuai", dan pernyataan yang dinilai pada skala 5 sebanyak 3 pernyataan atau sebesar $15 \%$, artinya "pernyataan sangat sesuai".

Hasil penilaian dari validator keempat (Fransina Silpa Songjanan, S.Pd) yaitu jumlah pernyataan yang dinilai pada skala 4 sebanyak 18 pernyataan atau sebesar $90 \%$, artinya "pernyataan sesuai", dan jumlah pernyataan yang dinilai pada skala 5 sebanyak 2 pernyataan atau sebesar $20 \%$, artinya "pernyataan sangat sesuai".

Berdasarkan hasil penilaian dari keempat validator tersebut, dapat disimpulkan bahwa desain produk rencana strategi yang telah dibuat sudah valid. Walaupun demikian, ada beberapa saran perbaikan yang diberikan oleh setiap validator. Oleh karena itu, sebelum produk diujicobakan maka perlu dilakukan perbaikan sesuai saran perbaikan dari keempat validator. 
Saran dari validator pertama (Prof. Dr. Slameto, M.Pd) di anataranya adalah: (1) kegiatan yang dirancang perlu dikurangi sehingga ada kegiatan yang dapat difokuskan sesuai dengan sumber dana dan tenaga yang tersedia; (2) rumusan strategi perlu disusun dengan konsep SMART (spesific, measureable, archieable, relevant, dan time). Saran dari validator kedua (Dr. Bambang Ismanto, M.Si) yaitu: (1) pada bagian latar belakang perlu dideskripsikan secara eksplisit sesuai keadaan sekolah; (2) pada bagian tujuan perlu dirumuskan ulang sesuai dengan masalah pada bagian latar belakang; (3) perlu dideskripsikan tanggapan atau saran dari sekolah pengguna. Saran dari validator ketiga (Dr. Yari Dwikurnaningsih, M.Pd) adalah pada bagian penutup perlu diuraikan secara komprehensif. Saran dari validator keempat (Fransina Silpa Songjanan, S.Pd) yaitu rencana strategi pemasaran perlu dibuat dalam periode jangka lima tahunan mengingat unsur-unsur marketing mix mencakup masalah-masalah yang luas.

\section{Revisi Desain}

Pada tahap ini dilakukan review terhadap hasil validasi produk oleh para validator. Hasil validasi berupa penilaian dan saran yang diberikan digunakan sebagai bahan revisi desain produk. Revisi desain produk terutama difokuskan pada pernyataan yang dinilai berada pada skala 2 dan skala 3 dan beberapa saran validator sesuai hasil validasi desain produk pada tahap sebelumnya.

\section{Uji Coba Produk}

Setelah desain produk rencana strategi direvisi, maka selanjutnya peneliti melakukan koordinasi dengan kepala SMA Negeri 5 Tual agar dilakukan uji coba secara terbatas. Uji coba terbatas ini dilakukan melalui FGD bersama pihak sekolah sebagai calon pengguna. Maksud FGD tersebut adalah untuk meminta persepsi atau pandangan calon pengguna terhadap produk rencana strategi yang telah dibuat. Persepsi atau pandangan tersebut berupa kelayakan dan estimasi pencapaian setiap program strategis dalam mengatasi permasalahan kuantitas peserta didik di SMA Negeri 5 Tual Tual.

Dari hasil FGD tersebut dapat disimpulkan bahwa: (1) produk renstra terperinci dan mudah dipahami; (2) strategi marketing mix yang digunakan merupakan strategi baru dan belum pernah diketahui sebelumnya oleh sekolah; (3) program strategis yang dirancang sesuai dengan kondisi sekolah; (4) program strategis dirasa dapat menguntungkan sekolah dalam hal biaya dan waktu; (5) produk renstra dirasa mudah dioperasikan oleh seluruh stakeholder sekolah; (6) produk renstra dirasa akan membantu SMA Negeri 5 Tual dalam meningkatkan kuantitas peserta didik; (7) saran perbaikan adalah beberapa kalimat perlu disusun dengan baik sesuai tata bahasa agar lebih operasional.

\section{Revisi Produk}

Berdasarkan hasil uji coba produk yang telah dilakukan di sekolah terhadap produk rencana strategi, maka selanjutnya adalah dilakukan perbaikan atau revisi produk rencana strategi tersebut. Revisi produk rencana starategi tersebut dipusatkan pada saran sekolah yang menyatakan bahwa beberapa kalimat di dalam produk perlu disusun dengan baik sesuai tata bahasa agar lebih operasional. Produk yang telah direvisi kemudian dibukukan dan diserahkan kepada pihak sekolah untuk dapat digunakan sebagai pedoman dalam memasarkan jasa pendidikannya.

\section{SIMPULAN DAN SARAN}

\section{Simpulan}

Dari hasil penelitian dan pembahasan yang telah dipaparkan di atas, maka dapat disimpulkan bahwa produk berupa rencana strategi marketing mix dalam meningkatkan kuantitas peserta didik di SMA Negeri 5 Tual, dihasilkan melalui langkah-langkah R \& D dengan terlebih dahulu menganalisis potensi dan masalah yang dihadapi sekolah. Selanjutnya dilakukan pengumpulan data dari aspek insternal dan aspek eksternal sekolah. Setelah data terkumpul kemudian dilakukan analisis terhadap faktor internal dan faktor eksternal melalui analisis SWOT. Hasil dari analisis SWOT berupa strategi yang berada 
pada kuadran IV (weakness- threats), yang mendukung strategi defensif. Berdasarkan strategi defensif tersebut, produk rencana strategi dikembangkan dengan menghasilkan beberapa strategi yaitu: (1) pengembangan program unggulan sekolah; (2) penataan manajemen planning programming budgeting system (PPBS) sekolah; (3) penataan tata ruang sekolah; (4) pemanfaatan media internet dan pameran sekolah sebagai saluran promosi sekolah; (5) perekrutan guru dan staf lainnya sesuai prioritas serta mengusulkan penambahan guru secara intensif kepada pemerintah; (6) peningkatan sarana dan prasarana melalui kerjasama dengan pemerintah, orang tua peserta didik, maupun pengusaha setempat; dan (7) perencanakan program pembelajaran yang dapat menarik perhatian peserta didik.

\section{Saran}

Saran untuk pihak sekolah terkait dengan rencana strategi marketing mix dalam meningkatkan peserta didik, adalah sebagai berikut:

1. Kepala sekolah perlu membuat sistem tata kelola dalam mengelola seluruh potensi yang dimiliki sekolah sehingga kegiatan pemasaran dapat berlangsung dengan baik. Selain itu, kepala sekolah juga perlu secara intensif membangun kemitraan dengan pemerintah dan masyarakat yang memiliki kepedulian terhadap pendidikan.

2. Setiap guru maupun staf lainnya harus mampu mengenal seluruh potensi sekolah sehingga dapat dimanfaatkan sebagai faktor pendukung dalam proses kegiatan pendidikan di sekolah. Selain itu, perlu adanya kerjasama yang baik antar sesama guru maupun staf lain dalam mendukung seluruh proses kegiatan pendidikan yang berlangsung di sekolah.

\section{DAFTAR RUJUKAN}

Arifin, Z. (2011). Penelitian pendidikan (metode paradigma baru). Bandung: PT Remaja Rosdakarya

Kotler, P \& Armstrong, G. (2016). Principles of marketing. (16th Edition). London: Pearson Education Inc.

Lockhart, J. M. (2011). How to market your school: A guide to marketing, public relations, and communication for school administrators. USA: Iunivers, Inc

Machali, I \& Hidayat, A. (2016). The handbook of education management: Teori dan praktik pengelolaan sekolah/ madrasah di Indonesia. Jakarta: Prenadamedia Group

Muhaimin. (2012). Manajemen pendidikan (aplikasinya dalam penyusunan rencana pengembangan sekolah/ madrasah). (Cetakan ke-4). Jakarta: Kencana Prenada Media Group.

Rangkuti, F. (2015). Analisis SWOT: Teknik membedah kasus bisnis. Jakarta: PT. Gramedia Pustaka Utama.

Robbins, S. \& Coulter, M. (2009). Management. New Jersey: Pearson Education.

Sallis, E. (2012). Total quality management in education. Yogyakarta: IRCiSoD.

Sugiyono. (2009). Metode penelitian kuantitatif, kualitatif, dan R \& D. Bandung: Alfabeta

Wijaya, D. (2012). Pemasaran jasa pendidikan "mengapa sekolah memerlukan marketing?". Jakarta: Salemba Empat. 